\title{
A highly prevalent filamentous algal endophyte in natural populations of the sugar kelp Saccharina latissima is not detected during cultivation in Northern Brittany
}

\author{
Miriam Bernard ${ }^{1, *}$, Sylvie Rousvoal ${ }^{1}$, Nadia Collet ${ }^{1}$, Tristan Le Goff ${ }^{2}$, Bertrand Jacquemin ${ }^{2}$, \\ Akira Peters ${ }^{3}$, Philippe Potin ${ }^{1}$ and Catherine Leblanc ${ }^{1}$ \\ ${ }^{1}$ Sorbonne Université, CNRS, UMR 8227, Integrative Biology of Marine Models, Station Biologique de Roscoff, Roscoff, France \\ 2 Centre d'Etude et de Valorisation des Algues, Pleubian, France \\ 3 Bezhin Rosko, 29250 Santec, France
}

Received 14 February 2019 / Accepted 11 August 2019

Handling Editor: Ryan B Carnegie

\begin{abstract}
The sugar kelp Saccharina latissima is cultivated in Europe for food, feed and ultimately the production of chemical commodities and bioenergy. Being cultivated in the open sea, S. latissima is exposed to potentially harmful organisms, such as Laminarionema elsbetiae, a filamentous brown algal endophyte with a very high prevalence in wild populations of European $S$. latissima. As it was shown previously that $S$. latissima sporophytes get infected by L. elsbetiae very early in their life, seeding the spores on collectors and keeping them under controlled conditions during the critical time of a possible infection with filamentous endophytes could be advantageous over direct seeding techniques, where the ropes are deployed within days after seeding. We used a qPCR-assay to assess the prevalence of the endophyte L. elsbetiae in S. latissima cultivated during winter in Northern Brittany, comparing individuals from direct-seeded ropes and collectorseeded lines that were kept in laboratory conditions for different time spans. No DNA of the endophyte was detected in the samples, suggesting that either the kelps were not infected or the amount of endophytic filaments were below the detection rate of the qPCR assay. Furthermore, L. elsbetiae could not be detected in the seawater surrounding the kelp farm, indicating that L. elsbetiae is not fertile or disperses at a very small scale in Northern Brittany during the deployment time of young kelps. Our results suggest that infections of cultivated S. latissima with the endophyte L. elsbetiae might be a minor problem in kelp farms in Northern Brittany if the seeding production is kept under controlled conditions without external contamination.
\end{abstract}

Keywords: Endophytes / seaweed aquaculture / Laminarionema elsbetiae / quantitative PCR / Saccharina latissima

\section{Introduction}

The sugar kelp Saccharina latissima is the closest European relative to the Asian S. japonica that contributes to one third of the global production of seaweed (Chung et al., 2017). S. latissima has a high carbohydrate content and is one of the fastest-growing European kelp species (Skjermo et al., 2014). While it has traditionally been collected from wild stocks for the use as a source of iodine, fertilizer in agriculture and as animal feed, today this species is cultivated in Europe for food, feed and the production of novel cosmetic and pharmaceutical products and ultimately bioenergy (Adams et al., 2009; Mesnildrey et al., 2012; Skjermo et al., 2014; Chen et al., 2015). Being cultivated in the open sea, S. latissima

*Corresponding author: miriambernard@gmx. de is exposed to potentially harmful organisms, such as viruses, fungi, bacteria or endophytic algae (Andrews, 1977; Wu et al., 1983; Apt, 1988; Potin et al., 2002) and also hosts various epibionts (L'Hardy, 1962; Seed, 1976). As these pathogens and pests are a crucial threat to the globally increasing kelp aquaculture, we need a better understanding of their life history, epidemiology and the interaction with their hosts (Gachon et al., 2010).

Endophytic algae invade stipes and fronds of kelps and their presence often coincides with severe disease signs, such as galls (Apt, 1988; Thomas et al., 2009), dark spots (Ellertsdóttir and Peters, 1997) or twisted stipes and blades (Peters and Schaffelke, 1996). They have also been reported to lower the commercial value of infected kelps (Yoshida and Akiyama, 1979). Amongst them is Laminarionema elsbetiae, a filamentous brown algal endophyte that infects up to $100 \%$ of 
individuals in European wild S. latissima populations (Peters and Ellertsdóttir, 1996; Ellertsdóttir and Peters, 1997; Bernard et al., 2018). Recently, a qPCR-assay was developed to detect and quantify the endophyte $L$. elsbetiae in infected thalli of its host $S$. latissima (Bernard et al., 2018). Using this method, it was shown that $S$. latissima sporophytes get infected by $L$. elsbetiae very early in their life and that environmental factors affect the endophytic prevalence and infection rates in wild Saccharina populations significantly (Bernard et al., 2018). However, the impact of endophytic infections on S. latissima cultivated in farms is still unclear.

In Europe, S. latissima and other kelp species are usually cultivated in the open sea during winter, with deployment of the seaweed lines between October and January, a main growth period during spring and harvesting before summer to avoid biofouling of the crop (Skjermo et al., 2014; Lüning and Mortensen, 2015; Mooney-McAuley et al., 2016). Kelp zoospores are released from sori of wild sporophytes and can either be seeded directly (Kim et al., 2017) or cultivated as gametophyte stock cultures under red light conditions for vegetative growth (Mooney-McAuley et al., 2016). In the latter case, fertility of the gametophyte culture is induced 2-3 weeks before seeding to obtain young sporophytes by transferring the cultures to blue-light conditions (Mooney-McAuley et al., 2016). Zoospores or young sporophytes can be seeded on collectors or on ropes directly. While collectors usually stay in the hatchery for up to two months until the young sporophytes reach a size of $1-5 \mathrm{~cm}$ and are transferred to long lines in the open sea, direct seeded ropes can be deployed within days after seeding (Pereira and Yarish, 2008; Edwards and Watson, 2011; Rolin et al., 2016).

In regard of endophytic infections, seeding the algal material on collectors and keeping it under controlled conditions during the critical time of a possible infection with filamentous endophytes could be advantageous over direct seeding techniques. We used a qPCR-assay (Bernard et al., 2018) to assess the prevalence of the endophyte $L$. elsbetiae in $S$. latissima cultivated during winter on the North-Western coast of Brittany, comparing individuals from direct-seeded ropes and collector-seeded lines that were kept in laboratory conditions for different time spans. The aim of this study was to test whether the use of collector-seeded lines instead of direct-seeded ropes could reduce the prevalence of L. elsbetiae in cultivated S. latissima.

\section{Material and methods}

\subsection{Algal and endophyte material}

30 fertile individuals of $S$. latissima (total weight $=1.2 \mathrm{~kg}$ ) were collected from a natural population in Port l'Epine at Trelevern $\left(48.82^{\circ} \mathrm{N}, 3.39^{\circ} \mathrm{W}\right)$ on $06 / 11 / 2017$.

Cultures of the filamentous endophyte $L$. elsbetiae were isolated from infected kelp hosts and cultivated in unialgal cultures in half-strength Provasoli enriched medium according to Bernard et al. (2018).

\subsection{Spore release and seeding procedure}

Spores were released by placing the sori in a $15 \mathrm{~L}$ tank for 2 hours at $15^{\circ} \mathrm{C}$. The resulting spore suspension was

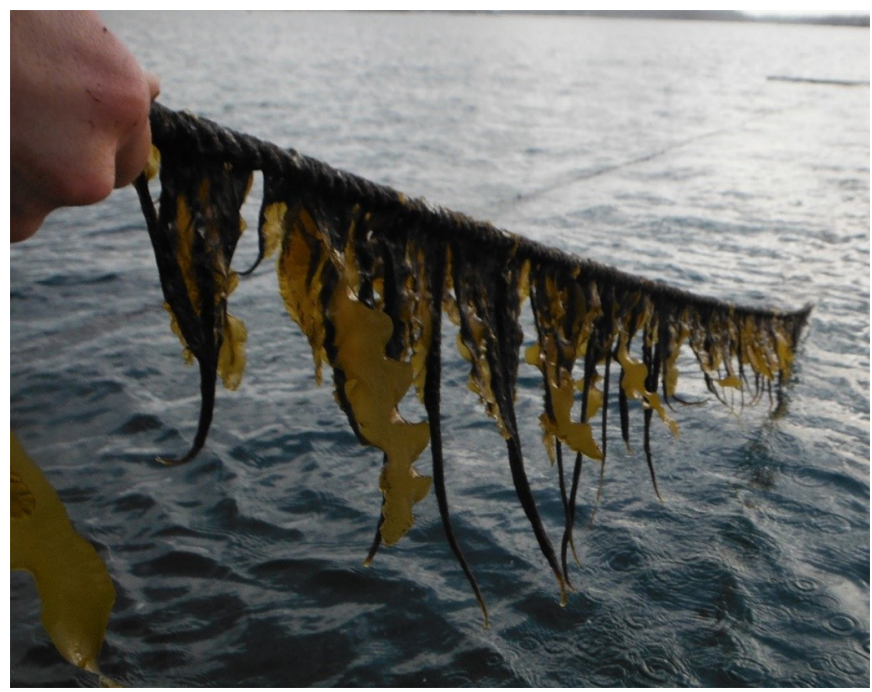

Fig. 1. Cultivation of Saccharina latissima on a $50 \mathrm{~m}$ rope at the cultivation site.

transferred to another tank and the release was repeated three times in order to increase the number of spores, resulting in a total amount of $60 \mathrm{~L}$ of spore suspension.

Half of the spore suspension was used for direct seeding. A $25 \mathrm{~m}$ polyethylene rope was placed in $90 \mathrm{~L}$ of filtered seawater $(1 \mu \mathrm{m})$ and $30 \mathrm{~L}$ of spore suspension were added. The spores settled directly on the rope. Additionally, the spore suspension was seeded on two collectors $(0.33 \mathrm{~m} \times 0.33 \mathrm{~m}$ PVC square frame $+55 \mathrm{~m}$ of Kuralon ${ }^{\circledR}$ string). Each collector was placed in $18 \mathrm{~L}$ of filtered seawater $(1 \mu \mathrm{m})$ and $3 \mathrm{~L}$ of spore suspension were added.

The rope and the two collectors were kept in the tanks with a photoperiod of $12 \mathrm{~h}$ light: $12 \mathrm{~h}$ dark cycle. After 6 days, the direct-seeded rope was transferred to the open sea cultivation site $\left(48.85^{\circ} \mathrm{N}, 3.05^{\circ} \mathrm{W}\right)$ in November 2017 . Collectors 1 and 2 were kept in the tank for 8 (beginning of January 2018) and 11 weeks (end of January 2018), respectively, before they were transferred to the cultivation site.

\subsection{Offshore cultivation}

The seeded Kuralon strings of the collectors were rolled on two polyethylene ropes of $12 \mathrm{~mm}$ diameter and $25 \mathrm{~m}$ long each and following the strands of the ropes. The $50 \mathrm{~m}$ ropes were then transferred to the cultivation site (Fig. 1). The ropes were horizontally fixed between moored floats and maintained at a constant depth of 0.5 to 2 meters (depending on the tides and currents, the distance between the floats would vary).

\subsection{Sampling}

For each sampling, 30 individuals were collected and pooled in triplets to 10 samples. Samples were taken after 8 (sampling date 1), 11 (sampling date 2) and 14 weeks (sampling date 3). Collector 1 was deployed 8 weeks after seeding. Samples were taken before deployment (sampling date 1) as well as 3 (sampling date 2) and 6 weeks (sampling date 3) after deployment. 


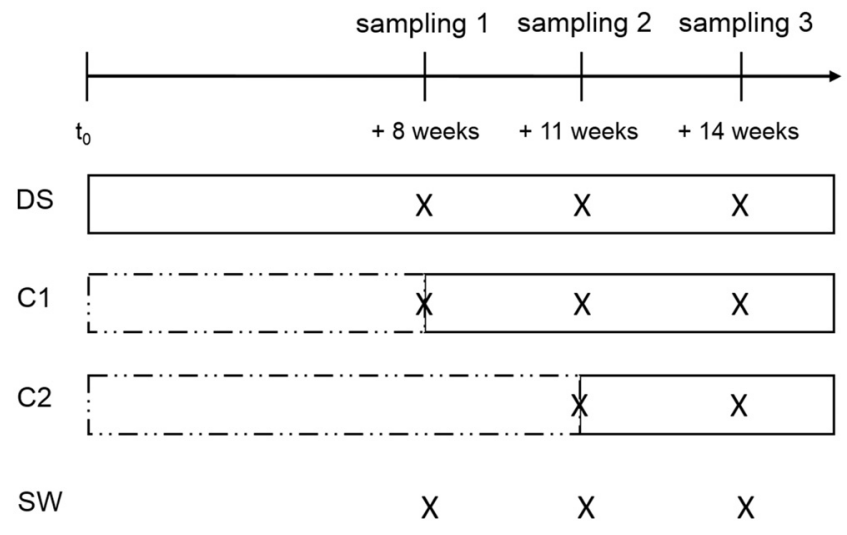

Fig. 2. Overview of the experimental design. Treatments: $\mathrm{DS}=$ direct seeded line, $\mathrm{C} 1=$ collector $1, \mathrm{C} 2=$ collector $2, \mathrm{SW}=$ seawater. $\mathrm{X}$ indicates the samplings, broken lines indicate the time of sporophytes grown in laboratory conditions and full lines the time of sporophytes grown in the field.

Collector 2 was deployed 11 weeks after seeding. Samples were taken before deployment (sampling date 2) and 3 weeks (sampling date 3) after deployment. An overview of the samplings is shown in Figure 2. The kelps were soaked dry with filter paper, transferred to silica gel and stored in silica gel until DNA extraction.

Three replicates of $1 \mathrm{~L}$ seawater were collected in the surrounding of the cultivation site at each sampling date (Fig. 2). The seawater was filtered through $3 \mu \mathrm{m}$ polycarbonate filters (Nucleopore Track-Etched Membranes, Whatman, GE Healthcare, USA) using a vacuum pump. Filters were transferred to tubes, frozen and kept in $-20^{\circ} \mathrm{C}$ until DNA extraction.

\subsection{DNA extraction}

The dried algal material was transferred to a $2 \mathrm{~mL}$ Eppendorf tube and ground in a mechanical bead grinder (Tissuelyser II, Qiagen, Germany) three times for $01 \mathrm{~min}$ at $30 \mathrm{~Hz}$. DNA was extracted using a CTAB-based chloroform/isoamyl alcohol extraction protocol as described in Bernard et al. (2018). DNA of the water samples was extracted from the frozen polycarbonate filters as described by Bernard et al. (2018).

DNA concentrations were measured with a Qubit Fluorometer (Thermo Fisher, USA) and all samples were diluted to $0.05 \mathrm{ng} / \mu \mathrm{l}$ with autoclaved milliQ-filtered $\mathrm{H}_{2} \mathrm{O}$. The concentration was chosen according to a previous studies using the same primer pairs (Gachon et al., 2009; Bernard et al., 2018).

\section{6 qPCR}

qPCR of the extracted DNA was performed with two different primer pairs: The first primer pair CG64 and CG65 (Gachon et al., 2009) matched the 18S rDNA of all Ectocarpales and Laminariales and was used to amplify $18 \mathrm{~S}$ rDNA from both, host and endophyte DNA. The second primer pair LelsITS1-F2 and LelsITS1-R2 (Bernard et al., 2018) specifically matched the partial ITS1 of L. elsbetiae. qPCR was
Table 1. Number of qPCR quantification cycles obtained from sample DNA using the general (CG) and endophyte specific (Lels) primer pair (Average \pm standard deviation, $\mathrm{N}=30$ ). Treatments: $\mathrm{DS}=$ direct seeded line, $\mathrm{C} 1=$ collector $1, \mathrm{C} 2=$ collector 2. n.d. $=$ not detected.

\begin{tabular}{llll}
\hline $\begin{array}{l}\text { Sampling } \\
\text { point }\end{array}$ & Treatment & CG & Lels \\
\hline 1 & DS & $21.1 \pm 0.6$ & n.d. \\
1 & C1 & $20.6 \pm 1$ & n.d. \\
2 & DS & $22.5 \pm 3$ & n.d. \\
2 & C1 & $18.9 \pm 0.4$ & n.d. \\
2 & C2 & $19.1 \pm 0.4$ & n.d. \\
3 & DS & $18.9 \pm 1.3$ & n.d. \\
3 & C1 & $19.2 \pm 0.6$ & n.d. \\
3 & C2 & $18.4 \pm 1.3$ & n.d. \\
\hline
\end{tabular}

performed as described by Bernard et al. (2018) on a Light Cycler 480 (Roche Life Science, Germany) in white 384 wellplates, sealed with adhesive foil. All samples were run in triplicates. DNA of L. elsbetiae was used as a positive control. A standard curve of the LelsITS1-F2 and LelsITS1-R2 was constructed in duplicates ranging from concentrations of $1 \mathrm{ng}$ to $1.28 \times 10^{-5} \mathrm{ng}$. Autoclaved milliQ $\mathrm{H}_{2} \mathrm{O}$ was used as negative control. For relative quantification, the differences between the quantification cycles $\left(\Delta \mathrm{C}_{\mathrm{q}}\right)$ obtained by two qPCRs with the different primer pairs run in parallel on the same DNA sample were measured. The resulting $\Delta \mathrm{C}_{\mathrm{q}}$ values correlate negatively to the relative amount of endophyte DNA in the sample.

\section{Results and discussion}

For all sampled individuals, $C_{q}$ values were obtained only with the CG primer pair, but not using the Laminarionema specific primer pair (Table 1), indicating that DNA of the kelp could be detected in the extracted samples, but not DNA of the endophyte. However, DNA of L. elsbetiae, which was used as a positive control, was detected reliably by $\mathrm{qPCR}$ in all tested concentrations (Table 2). These results either suggest that the kelps were not infected or that the amount of endophytic filaments were below the detection rate of the qPCR assay, i.e. below $1.28 \times 10^{-5} \mathrm{ng}$. Similar $C_{q}$ values were obtained for the three different lines and the result was independent of the seeding technique used as well as the amount of time spent in the hatchery before deployment (Table 1). Consequently, based on the results presented in this study we cannot infer how the choice of a seeding technique affects infections by L. elsbetiae in cultivated $S$. latissima. None of the samples showed disease signs or morphological changes after up to 14 weeks of growth in the seaweed farm (Fig. 3A+B).

Similar results were obtained for the environmental seawater samples. Whereas the general primer pair showed a positive signal, no $C_{q}$ values were obtained for the Laminarionema specific primer pair during any of the 3 sampling time points (Table 3), indicating that there were no or not enough spores of $L$. elsbetiae present in the sea water to be detectable by qPCR. 
Table 2. Number of qPCR quantification cycles obtained from $L$. elsbetiae DNA using the general (CG) and endophyte specific (Lels) primer pair.

\begin{tabular}{lll}
\hline Concentration $[\mathrm{ng}]$ & $\mathrm{CG}$ & Lels \\
\hline 1 & 14.2 & 15.1 \\
1 & 14.3 & 15 \\
0.2 & 16.7 & 17.7 \\
0.2 & 16.9 & 17.7 \\
0.04 & 19.7 & 20.8 \\
0.04 & 19.8 & 20.8 \\
0.008 & 22.3 & 23.3 \\
0.008 & 22.6 & 23.1 \\
0.0016 & 24.6 & 25.8 \\
0.0016 & 24.7 & 25.6 \\
0.00032 & 27 & 28.3 \\
0.00032 & 27.2 & 28.2 \\
0.000064 & 29.5 & 30.8 \\
0.000064 & 29.2 & 30.8 \\
0.0000128 & 30.9 & 33 \\
0.0000128 & 32.3 & 33.6 \\
\hline
\end{tabular}

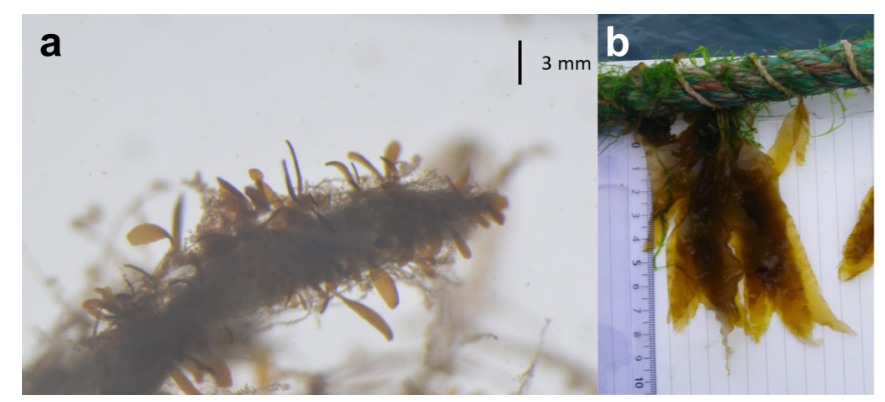

Fig. 3. (A) 20-day-old Saccharina latissima sporophytes on a Kuralon string. (B) 90-day-old S. latissima sporophytes on a long line.

Laminarionema elsbetiae is the most common endophyte in European S. latissima populations (Ellertsdóttir and Peters, 1997; Bernard et al., 2019). It spreads via zoospores that are released from plurilocular sporangia on infected host plants (Peters and Ellertsdóttir, 1996; Heesch and Peters, 1999), infecting young kelp tissue which makes the early sporophytes deployed in farms exceptionally threatened (Bernard et al., 2018). In order to infect $S$. latissima sporophytes in kelp farms, the fertility period of the endophyte needs to be concurrent with the deployment time of young kelps. Although $L$. elsbetiae spores have been observed in Helgoland and Brittany in the end of March (Peters and Ellertsdóttir, 1996; Bernard et al., 2018), spore release by the endophyte has never been followed over the course of a year and it is unclear when the endophyte releases its spores at other localities. Furthermore, the mechanism of spore release of Laminarionema is still unknown. Algal spore release is often controlled by abiotic factors, such as light and temperature conditions (Amsler and Neushul, 1989; Ganesan et al., 1999) or desiccation (Suto, 1952). It may, however, also involve more complex mechanisms such as cross-talk, i.e. bidirectional biochemical
Table 3. Number of qPCR quantification cycles obtained by DNA of the seawater samples (Average \pm standard deviation, $N=3$ ). n.d. $=$ not detected. $\mathrm{CG}=$ primer pair CG64/65, Lels $=$ Laminarionema specific primer pair.

\begin{tabular}{lll}
\hline $\begin{array}{l}\text { Sampling } \\
\text { point }\end{array}$ & CG & Lels \\
\hline 1 & $29.1 \pm 0.6$ & n.d. \\
2 & $28.4 \pm 0.2$ & n.d. \\
3 & $25.2 \pm 0.8$ & n.d. \\
\hline
\end{tabular}

interaction, with hosts or the presence of bacteria (Weinberger et al., 2007).

The closest natural population of S. latissima - i.e. the closest source of $L$. elsbetiae spores in the seawater - was located at $1 \mathrm{~km}$ distance from the experimental site at the seaweed farm. Since no endophyte spores were detected in the seawater during our experiments, it can be concluded that either no fertile L. elsbetiae was present in the natural Saccharina population during January and February, or that the $1 \mathrm{~km}$ distance could not be covered by the endophyte spores. However, since it has been shown that brown algal spores may disperse over distances of several kilometres, depending on abiotic and biotic factors (Gaylord et al., 2002, 2006; Reed et al., 2004), we hypothesize that L. elsbetiae was not fertile during the time of the experiment. Further studies on the life cycle and the spore release of L. elsbetiae in nature are necessary to confirm these results.

Not only infections with algal endophytes, but also other biotic stresses in kelp aquaculture are avoided by the common cultivation time of $S$. latissima in Europe starting in late autumn or winter. Biofouling and epiphytic animals, like bryozoans, amphipods or gastropods or polychaetes, which are a major constraint to $S$. latissima aquaculture, start to appear in early summer and are highly abundant from June onwards (Forbord et al., 2012; Handå et al., 2013; Lüning and Mortensen, 2015). Saccharina latissima is therefore usually harvested in May or June (Peteiro and Freire, 2009; Stévant et al., 2017). Furthermore, the growth rates and yield of $S$. latissima cultivated over winter from December to April have been shown to be higher than those of individuals grown between February and May (Peteiro and Freire, 2009).

Since no endophyte infection was detected in this study, the impact of seeding techniques on infection rates could not be compared. Instead, our results suggest that infections of $S$. latissima by the endophyte $L$. elsbetiae might be a minor problem in kelp farms in Northern Brittany independent of the seeding technique, under the premise that the entire seeding procedure is performed under controlled conditions without external contamination. However, as the life cycle of $L$. elsbetiae in nature is largely unexplored, no generalizations of these results can be made for other localities. Overall, the nature and epidemiology of seaweed pathogens are still largely understudied (Loureiro et al., 2015) and there is a large number of other potential pathogens that present a potential thread to seaweed aquaculture. We therefore want to stress the importance of the qPCR assay for sample and water monitoring in kelp farms and hatcheries. It is easily adaptable for routine application and processing large sample numbers 
and can be transferred to other host-pathogen pairs by designing specific primer pairs. Such tools are already used routinely in terrestrial agriculture (Miller et al., 2009) and animal mariculture (Sepúlveda et al., 2013) and will facilitate a sustainable development of seaweed cultivation.

Acknowledgements. This project has received funding from the European Union's Horizon 2020 research and innovation programme under the Marie Skłodowska-Curie grant agreement $\mathrm{N}^{\circ}$ 642575. It was supported by the French National Research Agency via the 'Investment for the Future' project IDEALG (no. ANR-10-BTBR-04) and the European Union Horizon's 2020 programme (grant agreement number 727892 , GENIALG - GENetic diversity exploitation for Innovative macro-ALGal biorefinery, http:/genialgproject.eu/). We would also like to thank the reviewer for providing critical comments that helped to improve the manuscript.

\section{References}

Adams JM, Gallagher JA, Donnison IS. 2009. Fermentation study on Saccharina latissima for bioethanol production considering variable pre-treatments. J Appl Phycol 21: 569-574.

Amsler CD, Neushul M. 1989. Diel periodicity of spore release from the kelp Nereocystis luetkeana (Mertens) Postels et Ruprecht. $J$ Exp Mar Biol Ecol 134: 117-127.

Andrews JH. 1977. Observations on the pathology of seaweeds in the Pacific Northwest. Can J Bot 55: 1019-1027.

Apt KE. 1988. Galls and tumor-like growths on marine macroalgae. Dis Aquat Organ 4: 211-217.

Bernard M, Rousvoal S, Jacquemin B, Ballenghien M, Peters AF, Leblanc C. 2018. qPCR-based relative quantification of the brown algal endophyte Laminarionema elsbetiae in Saccharina latissima: variation and dynamics of host - endophyte interactions. J Appl Phycol 30: 2901-2911.

Bernard MS, Strittmatter M, Murúa P, Heesch S, Cho GY, Leblanc C, Peters AF. 2019. Diversity, biogeography and host specificity of kelp endophytes with a focus on the genera Laminarionema and Laminariocolax (Ectocarpales, Phaeophyceae). Eur J Phycol 54: 39-51.

Chen H, Zhou D, Luo G, Zhang S, Chen J. 2015. Macroalgae for biofuels production: progress and perspectives. Renew Sust Energy Rev 47: 427-437.

Chung IK, Sondak CFA, Beardall J. 2017. The future of seaweed aquaculture in a rapidly changing world. Eur J Phycol 52: 495-505.

Edwards M, Watson L. 2011. Cultivating Laminaria digitata. Aquaculture Explained. Irish Sea Fisheries Board.

Ellertsdóttir E, Peters AF. 1997. High prevalence of infection by endophytic brown algae in populations of Laminaria spp. (Phaeophyceae). Mar Ecol Prog Ser 146: 135-143.

Forbord S, Skjermo J, Arff, J, Handa H, Reitan KIR, Bjerregaard R, Lüning K. 2012. Development of Saccharina latissima (Phaeophyceae) kelp hatcheries with year-round production of zoospores and juvenile sporophytes on culture ropes for kelp aquaculture. $J$ Appl Phycol 24: 393-399.

Gachon CMM, Strittmatter M, Mueller DG, Kleinteich J, Kuepper FC. 2009. Detection of differential host susceptibility to the marine oomycete pathogen Eurychasma dicksonii by real-time PCR: not all algae are equal. Appl Environ Microbiol 75: 322-328.

Gachon CMM, Sime-Ngando T, Strittmatter M, Chambouvet A, Kim GH. 2010. Algal diseases: spotlight on a black box. Trends Plant Sci 15: 633-640.
Ganesan M, Mairh OP, Eswaran K, Rao PVS. 1999. Effect of UV radiation and other environmental factors on the liberation of tetraspores from brown alga Padina boergesenii (Phaeophyta, Dictyotales). Indian J Mar Sci 28: 50-54.

Gaylord B, Reed DC, Raimondi PT, Washburn L, McLean SR. 2002. A physically based model of macroalgal spore dispersal in the wave and current-dominated nearshore. Ecology 83: 1239-1251.

Gaylord B, Reed DC, Raimondi PT, Washburn L. 2006. Macroalgal spore dispersal in coastal environments: mechanistic insights revealed by theory and experiment. Ecol Monogr 76: 481-502.

Handå A, Forbord S, Wang X, Broch OJ, Dahle SW, Størseth TR, Reitan KI, Olsen Y, Skjermo J. 2013. Seasonal- and depthdependent growth of cultivated kelp (Saccharina latissima) in close proximity to salmon (Salmo salar) aquaculture in Norway. Aquaculture 414-415: 191-201.

Heesch S, Peters AF. 1999. Scanning electron microscopy observation of host entry by two brown algae endophytic in Laminaria saccharina (Laminariales, Phaeophyceae). Phycol Res 47: 1-5.

Kim JK, Yarish C, Hwang EK, Park M, Kim Y. 2017. Seaweed aquaculture: cultivation technologies, challenges and its ecosystem services. Algae 32: 1-13.

L'Hardy JP. 1962. Observations sur le peuplement epiphyte des lames de Laminaria saccharina (Linné) Lamouroux en Baie de Morlaix (Finistère). Cah Biol Mar 3: 115-227.

Loureiro R, Gachon CMM, Rebours C. 2015. Seaweed cultivation: potential and challenges of crop domestication at an unprecedented pace. New Phytol 206: 489-492.

Lüning K, Mortensen L. 2015. European aquaculture of sugar kelp (Saccharina latissima) for food industries: iodine content and epiphytic animals as major problems. Bot Mar 58: 449-455.

Mesnildrey L, Jacob C, Frangoudes K, Renauvot M, Lesueur M. 2012. Seaweed industry in France. Report. Interreg program NETALGAE. Les publications du Pôle halieutique Agrocampus Ouest $n^{\circ}$ 9: 34 p.

Miller SA, Beed FD, Harmon CL. 2009. Plant disease diagnostic capabilities and networks. Ann Rev Phytopathol 47: 15-38.

Mooney-McAuley KM, Edwards MD, Champenois J, Gorman E. 2016. Best Practice Guidelines for Seaweed Cultivation and Analysis, Public Output report of the EnAlgae project, Swansea.

Pereira R, Yarish C. 2008. Mass Production of Marine Macroalgae. In: Jørgensen SE, Fath BD (Eds.) Ecological Engineering. Vol. [3] of Encyclopedia of Ecology. Oxford: Elsevier.

Peteiro C, Freire Ó. 2009. Effect of outplanting time on commercial cultivation of kelp Laminaria saccharina at the southern limit in the Atlantic coast, N.W. Spain. Chin J Oceanol Limnol 27: 54-60.

Peters AF, Ellertsdóttir E. 1996. New record of the kelp endophyte Laminarionema elsbetiae (Phaeophyceae, Ectocarpales) at Helgoland and its life history in culture. Nov Hedwig 62: 341-349.

Peters AF, Schaffelke B. 1996. Streblonema (Ectocarpales, Phaeophyceae) infection in the kelp Laminaria saccharina (Laminariales, Phaeophyceae) in the western Baltic. Hydrobiol. 326-327: 111-116.

Potin P, Bouarab K, Salaün J-P, Pohnert G, Kloareg K. 2002. Biotic interactions of marine algae. Curr Opp Plant Biol 5: 308-317.

Reed DC, Schroeter SC, Raimondi PT. 2004. Spore supply and habitat availability as sources of recruitment limitation in the giant kelp Macrocystis pyrifera (Phaeophyceae). J Phycol 40: 275-284.

Rolin C, Inkster R, Laing J, Hedges J, McEvoy L. 2016. Seaweed cultivation manual: Shetland seaweed growers project 2014-16. 
Seed R. 1976. Observations on the ecology of Membranipora (Bryozoa) and a major predator Doridella steinbergae (Nudibranchiata) along the fronds of Laminaria saccharina at Friday Harbor, Washington. J Exp Mar Biol Ecol 24: 1-17.

Sepúlveda D, Bohle H, Labra Á, Grothusen H, Marshall SH. 2013. Design and evaluation of a unique RT-qPCR asay for diagnostic quality control assessment that is applicable to pathogen detection in three species of salmonid fish. BMC Vet Res 9: 183.

Skjermo J, Aasen IM, Arff J, Broch OJ, Carvajal A, Christie H, Forbord S, Olsen Y, Reitan KI, Rustad T, Sandquist J, Solbakken R, Steinhovden KB, Wittgens B, Wolff R, Handa A. 2014. A new Norwegian bioeconomy based on cultivation and processing of seawe eds Opportunities and R\&D needs. SINTEF Fisheries and Aquaculture.

Stévant P, Rebours C, Chapman A. 2017. Seaweed aquaculture in Norway: recent industrial developments and future perspectives. Aquacult Int 25: 1373-1390.
Suto S. 1952. On shedding of zoospores in some algae of Laminariaceae-II. Bull Jpn Soc Sci Fish 18: 1-5.

Thomas D, Beltrán J, Flores V, Contreras L, Bollmann E, Correa JA. 2009. Laminariocolax sp. (phaeophyceae) associated with gall developments in Lessonia nigrescens (phaeophyceae). J Phycol 45: $1252-1258$.

Weinberger F, Beltran J, Correa JA, Lion U, Pohnert G, Kumar N, Steinberg P, Kloareg B, Potin P. 2007. Spore release in Acrochaetium sp. (Rhodophyta) is bacterially controlled. J Phycol 43: 235-241.

Wu C, Chen D, Li J. 1983. On the diseases of cultivated Laminaria japonica. Academia Sinica 763.

Yoshida T, Akiyama K. 1979. Streblonema (Phaeophyceae) infection in the frond of cultivated Undaria (Phaeophyceae). In: Proceedings of the 9th International Seaweed Symposium. Santa Barbara: Science Press, pp. 213-223.

Cite this article as: Bernard M, Rousvoal S, Collet N, Le Goff T, Jacquemin B, Peters A, Potin P, Leblanc C. 2019. A highly prevalent filamentous algal endophyte in natural populations of the sugar kelp Saccharina latissima is not detected during cultivation in Northern Brittany. Aquat. Living Resour. 32: 21 